\title{
ヒト膝蓋腱および前十字靯帯の力学的性質と大腿四頭筋筋力の関係*
}

山本 憲隆*1, 高辻 勇貴 ${ }^{* 2}$

\section{Relationships between the Quadriceps Strength and the Mechanical Properties of Patellar Tendons and Anterior Cruciate Ligaments in Humans}

\author{
Noritaka YAMAMOTO*1 $^{* 1}$ and Yuki TAKATSUJI \\ ${ }^{* 1}$ Ritsumeikan Univ. Dept. of Mechanical Engineering \\ Noji-higashi 1-1-1, Kusatsu-shi, Shiga, 525-8577 Japan
}

\begin{abstract}
The mechanical properties of patellar tendons and anterior cruciate ligaments were in vivo evaluated in twelve male subjects. The deformation of patellar tendons was measured during isometric knee extension contractions using ultrasonography. The stiffness, cross-sectional area, and tangent modulus of the patellar tendons were positively correlated with the maximum quadriceps strength. The anterior displacement of tibiae was measured during the anterior drawer of the tibiae. There was no significant correlation between the anterior displacement and the maximum quadriceps strength. These results indicated that the stiffness, cross-sectional area, and tangent modulus of the patellar tendons were larger in the subjects with the larger quadriceps strength but the stiffness of the anterior cruciate ligaments was constant.
\end{abstract}

Key Words : Biomechanics, Mechanical Properties, Patellar Tendon, Anterior Cruciate Ligament, Quadriceps Strength

\section{1. 緒言}

運動によって筋力が増大寸ることは良く知られている.これに対して, 腱や勒帯の強度や剛性が増大寸るかど うかについては，まだ明確な解答が得られていない，従来，このようなリモデリングに関する研究は，実験動物 を用いて行われてきた ${ }^{(1)-(10)}$. イヌやブタなどをトレッドミル上で運動させた後, 腱や勒帯を摘出し, 引張試験が 行われている，その結果，強度や岡性が大きくなったという報告があるが，変化しなかったという報告もある. また, 最近は, ヒトを対象に, 腱の剛性に及ぼす運動の影響について検討されている(11)-(20). これらの研究では, 腱の力学的性質は, 筋の収縮力によって生じる腱の伸びを超音波診断装置で捉えることにより, 計測されている.

しかし，動物実験の結果と同様に，剛性が大きくなったという報告や変化しなかったという報告があり，得られ た結果は各々の研究で異なっている.

膝関節にある膝蓋腱は大腿四頭筋の筋力を脛骨に伝達する働きを担っているので，大腿四頭筋の筋力が大きく なると，膝蓋腱に作用する負荷が大きくなる．このため，膝蓋腱の力学的性質と大腿四頭筋の筋力の間には相関 関係が存在すると考えられる，そこで，我々は，超音波診断装置を用いてヒト膝蓋腱の力学的性質を生体内で計 測し，大腿四頭筋の筋力との関係について検討した ${ }^{(21)}$. その結果，大腿四頭筋の最大筋力が大きな被験者では， 膝蓋腱の剛性が大きいことが明らかになった，一方，前十字勒帯は，膝関節内で大腿骨と脛骨を連結しており， 脛骨に作用する筋力や外力に抗して膝を安定させる働きを担っている. このため, 前十字勒帯の力学的性質と大 腿四頭筋の筋力の間にも何らかの相関関係が存在すると考えられるが，前十字勒帯のリモデリングに関する研究 はまだ行われていない.

本研究では, 各被験者において, 膝蓋腱の力学的性質を計測するとともに, 前十字勒帯の力学的性質を前方引

* 原稿受付 2011 年 11 月 7 日

*1 正員, 立命館大学（干525-8577 滋賀県草津市野路東 1-1-1）

*2 立命館大学大学院 理工学研究科

E-mail: noritaka@se.ritsumei.ac.jp 
き出し試験により推定し, 大腿四頭筋の筋力との関係について検討した.

\section{2. 実験}

\section{$2 \cdot 1$ 被験者}

被験者は下肢に傷害の既往がない健常成人男性 12 名である。年齢は $21.5 \pm 0.5$ 歳（平均土標準誤差），体重は $66.4 \pm 3.0 \mathrm{~kg}$, 身長は $174.6 \pm 2.0 \mathrm{~cm}$ であった．各被験者に対して，膝蓋腱と前十字勒帯の力学的性質，および大腿 四頭筋の最大筋力の計測を実施した。 なお，被験者には，本研究の趣旨を十分に説明し，本実験への参加につい て同意を得た。

\section{$2 \cdot 2$ 膝蓋腱の力学的性質の計測}

膝蓋腱の力学的性質に関する計測方法は前報 (21) と同様である. 被験者を膝屈曲角度 $90^{\circ}$ でイスに座らせた（図 1). 膝蓋腱の長さ $L_{\mathrm{P}}$ を計測するために, 超音波診断装置（Nemio10，東芝メディカルシステムズ）のリニアプロ ーブ (PLF-308P, 周波数 5.0MHz) を膝蓋骨, 膝蓋腱, 脛骨が写るように膝に押し当てた. また, 膝伸展力 $F_{\mathrm{L}}$ を 計測するために，脛骨の関節面から $L_{\mathrm{y}}(300 \mathrm{~mm})$ の位置にロープを用いてロードセルを取り付けた. 被験者は, この状態で膝屈曲角度を一定に保ち, 大腿四頭筋の等尺性収縮により膝を伸展させた．超音波画像はビデオタイ マーを介してS-VHSに録画し，ロードセルで計測した膝伸展力 $F_{\mathrm{L}}$ のデータと同期を取った.

得られた超音波画像の典型的な例を図 2 に示寸. 膝蓋腱の長さ $L_{\mathrm{P}}$ は, 膝蓋骨の遠位端から脛骨粗面までの距離 とし, 超音波診断装置に付属の画像処理機能を用いて決定した. 荷重時の長さ $L_{\mathrm{P}}$ から無荷重時の初期長さ $L_{\mathrm{P} 0}$ を引 くことにより, 膝蓋腱の伸び $\Delta L_{\mathrm{P}}$ を求めた.

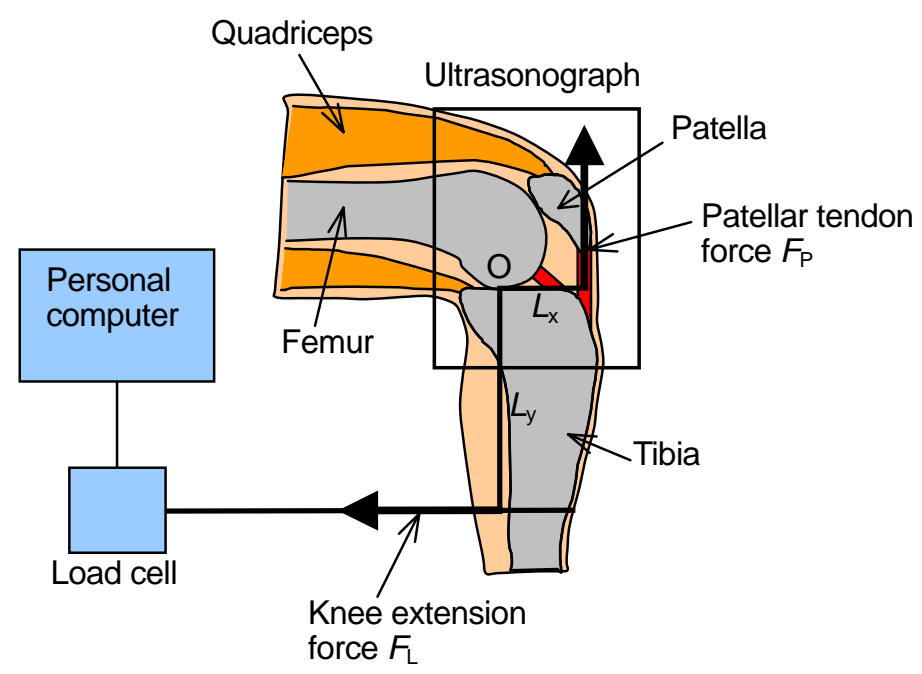

Fig. 1 Schematic diagram of measuring the mechanical properties of the patellar tendon.

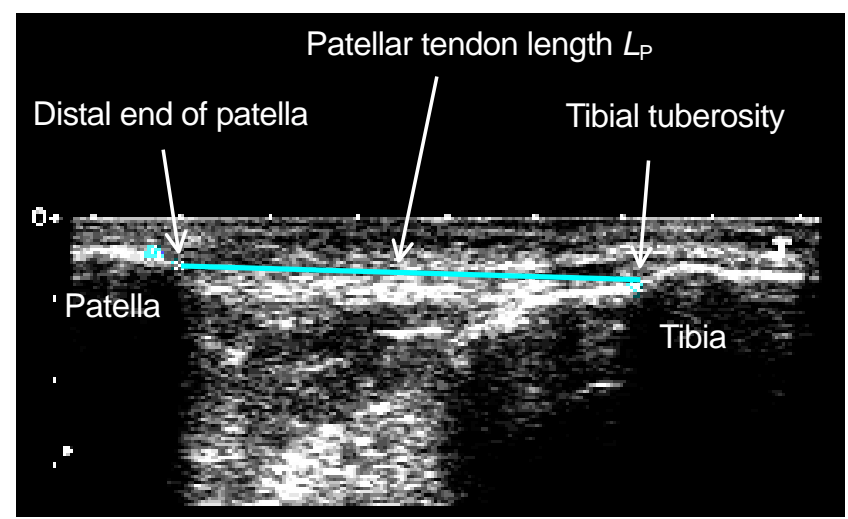

Fig. 2 Typical ultrasound image of the patellar tendon. 
膝蓋腱に作用寸る力 $F_{\mathrm{p}}$ 求めるために，図 1 に示寸膝関節の力学モデルを仮定した，大腿骨と脛骨の接触点を 中心Oとした．Ｏ点から膝蓋腱に下ろした垂線（膝蓋腱のモーメントアーム）の長さは $L_{\mathrm{x}}, \mathrm{O}$ 点からロードセルの 取り付け位置までの長さは $L_{\mathrm{y}}$ である. O点まわりのモーメントのつり合いより, 膝蓋腱力は, $F_{\mathrm{P}}=F_{\mathrm{L}} \times\left(L_{\mathrm{y}} / L_{\mathrm{x}}\right)$ と なる. 膝蓋腱のモーメントアーム長さ $L_{\mathrm{x}}$ は, 膝伸展の実験とは別に, 前もって計測しておいた. 被験者を膝屈曲 角度 $90^{\circ}$ でイスに座らせ，超音波診断装置のコンベックスプローブ（PVM-375AT，周波数 4.2MHz）をO点と膝 蓋腱が写るように膝に押し当てた. 被験者には大腿四頭筋の収縮が起こらないように注意した. 得られた超音波 画像から，超音波診断装置に付属の画像処理機能を用いて，膝蓋腱のモーメントアーム長さ $L_{\mathrm{x}}$ を決定した.

次に, 膝蓋腱の断面積を計測するために, 被験者を膝屈曲角度 $90^{\circ}$ でイスに座らせ, 超音波診断装置のリニア プローブ（PLM-805AT，周波数 12.0MHz）を膝蓋腱の断面が写るように膝に押し当てた．被験者には大腿四頭筋 の収縮が起こらないように注意した，得られた膝蓋腱の断面像から，超音波診断装置に付属の画像処理機能を用 いて断面積を決定した。計測は膝蓋腱の近位部，中央部，遠位部の 3 力所で行い，得られた值の平均值を膝蓋腱 の断面積 $A_{\mathrm{p}}$ とした.

剛性 $S_{\mathrm{P}}$ は, 膝蓋腱力 $F_{\mathrm{P}}$ と伸び $\Delta L_{\mathrm{P}}$ の関係において, 伸びが大きな領域で現れる直線部分の傾きとした．膝蓋腱 に作用する応力 $\sigma_{\mathrm{P}}$ は, 膝蓋腱力 $F_{\mathrm{P}}$ を断面積 $A_{\mathrm{P}}$ で割ることにより算出した. 膝蓋腱のひずみ $\varepsilon_{\mathrm{p}}$ は, 伸び $\Delta L_{\mathrm{P}}$ 初期長 さ $L_{\mathrm{P} 0}$ で割ることにより算出した，接線弾性係数 $E_{\mathrm{P}}$ は，応力ーひずみ関係において，ひずみが大きな領域で現れる 直線部分の傾きとした.

\section{$2 \cdot 3$ 前十字勒帯の力学的性質の計測}

前十字勒帯は大腿骨と脛骨を連結しており（図 3), 脛骨が前方に引き出されるのを抑制する働きを担っている (22). このため, 前十字勒帯の剛性が大きくなると脛骨の前方移動量が小さくなる. そこで, 本実験では, 脛骨に 前方荷重をかけたときの前方移動量から, 前十字勒帯の剛性を推定した.

被験者を膝屈曲角度 $90^{\circ}$ でイスに座らせた（図 3). 高周波差動トランス変位計（ST-2，ノーブル産業）を固定 したフレームを脛骨にマジックテープで取り付けた，このとき, 差動トランスのロッドの先端が膝蓋骨中央部に 当たるようにして, 膝蓋骨に対する脛骨の移動量を計測した. 荷重の測定にはロードセルを用いた. ロードセル の両端にロープをつなぎ，ロープの一方は脛骨の近位部に取り付け，他方は測定者が手で持ち引張った．約 5 秒 間で荷重が $100 \mathrm{~N}$ に達するように負荷と除荷を 10 回繰り返し, 荷重 $F_{\mathrm{T}}$ と移動量 $D_{\mathrm{T}}$ の関係を求めた. 10 回目に得ら れた結果において, 荷重 $100 \mathrm{~N} て ゙ の$ 移動量を脛骨の前方移動量 $D_{\mathrm{TA}}$ とした. 試験中は, 被験者には膝に力を入れな いようにリラックスしてもらい, 筋収縮が起こらないように注意した.

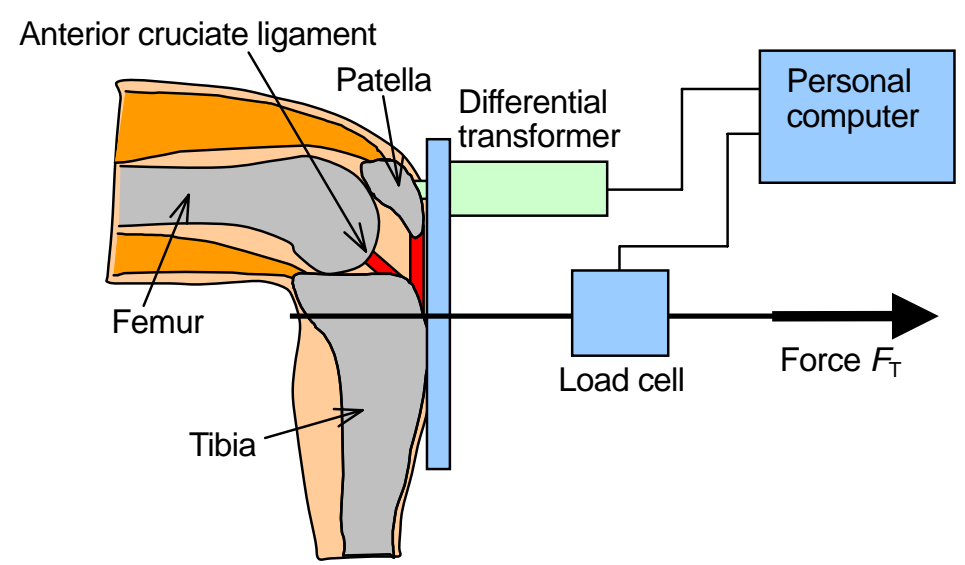

Fig. 3 Schematic diagram of anterior drawer test for estimating the stiffness of the anterior cruciate ligament.

\section{$2 \cdot 4$ 大腿四頭筋の最大筋力の計測}

被験者を膝屈曲角度 $90^{\circ}$ でイスに座らせ，下肢の関節面から $L_{\mathrm{y}}$ の位置にロープを用いてロードセルを取り付け た（図 1). 膝屈曲角度を保った状態で, 大腿四頭筋の等尺性収縮により膝を 1 回だけ力いっぱい伸展させた. こ のとき得られた膝伸展力の最大值から， 2.2 節と同様の方法で, 膝蓋腱に作用寸る力の最大值 $F_{\mathrm{Pmax}}$ を求め, この 值を大腿四頭筋の最大筋力とした. 


\section{$2 \cdot 5$ 統計解析}

有意差検定には，単回帰分析を用い， $p<0.05$ で有意差有りとした.

\section{3. 結果}

\section{$3 \cdot 1$ 膝蓋腱の力学的性質と大腿四頭筋の最大筋力の関係}

得られた膝蓋腱の応力ーひずみ関係の典型的な例を図 4 に示す. 計測值を黒点でプロットし，ひずみ 0 ～7\%の 区間で 2 次の多項式近似により曲線を描いた。ひずみが小さい領域では下に凸の曲線が現れたが，その後ひずみ が大きくなるとほぼ線形になった。この線形領域 (ひずみ 5〜7\%の区間) で線形近似により直線 (赤線)を描き, この直線の傾きを接線弾性係数 $E_{\mathrm{p}}$ とした.

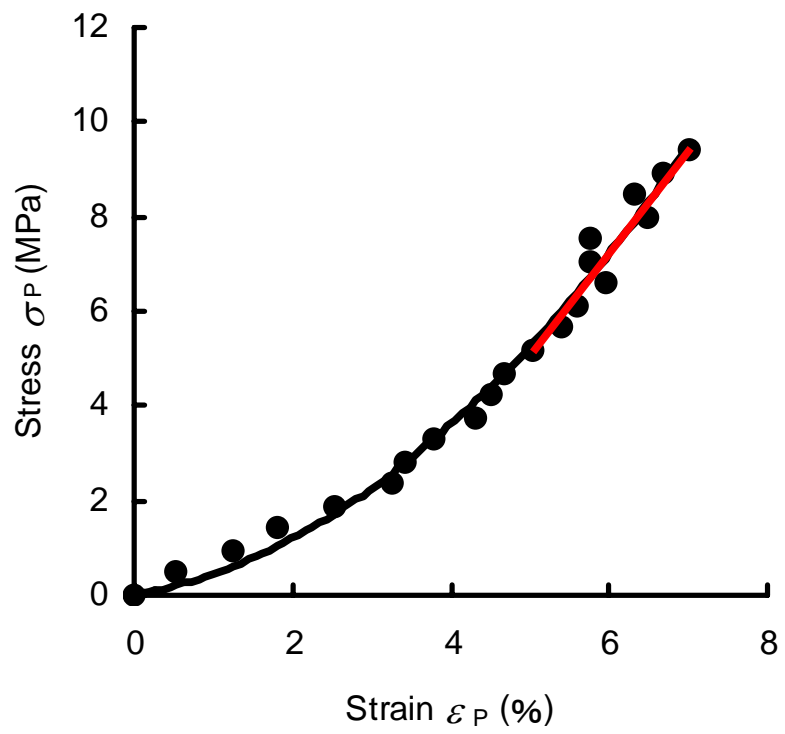

Fig. 4 Typical stress-strain curve of the patellar tendon.

被験者 12 名における膝蓋腱の剛性と大腿四頭笳の最大筋力の関係を図 5 に示寸. 剛性は最大筋力と有意な相関 関係にあり, 最大筋力が大きいほど剛性は大きくなった，同様に，膝蓋腱の断面積と接線弾性係数も大腿四頭笳 の最大筋力と有意な相関関係にあり, 最大筋力が大きいほど断面積と接線弾性係数が大きくなった (図 6, 7). こ れらの結果は, 本研究とは異なる 10 名の被験者を対象に実施した前報 ${ }^{(21)}$ の結果と同様であった.

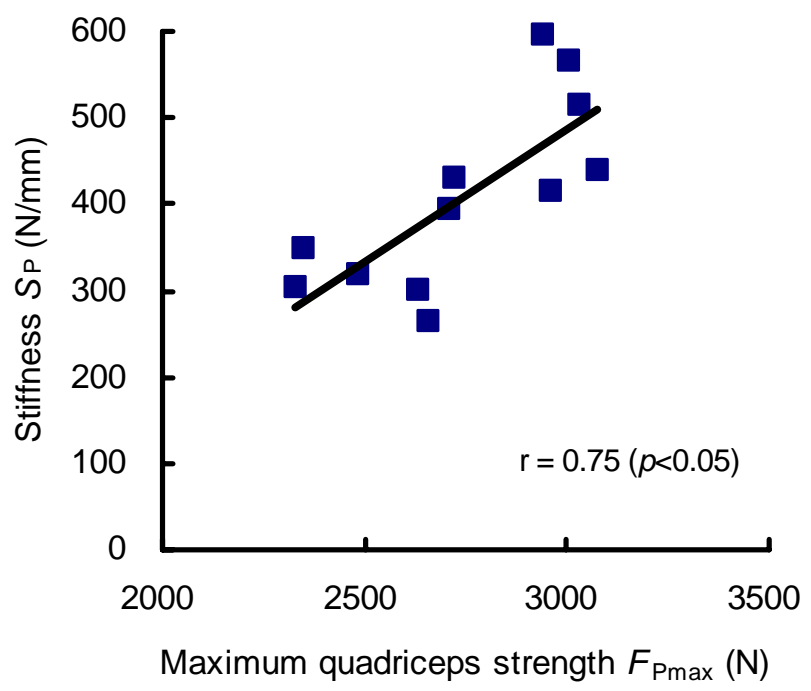

Fig. 5 Relationship between the patellar tendon stiffness and the maximum quadriceps strength. 


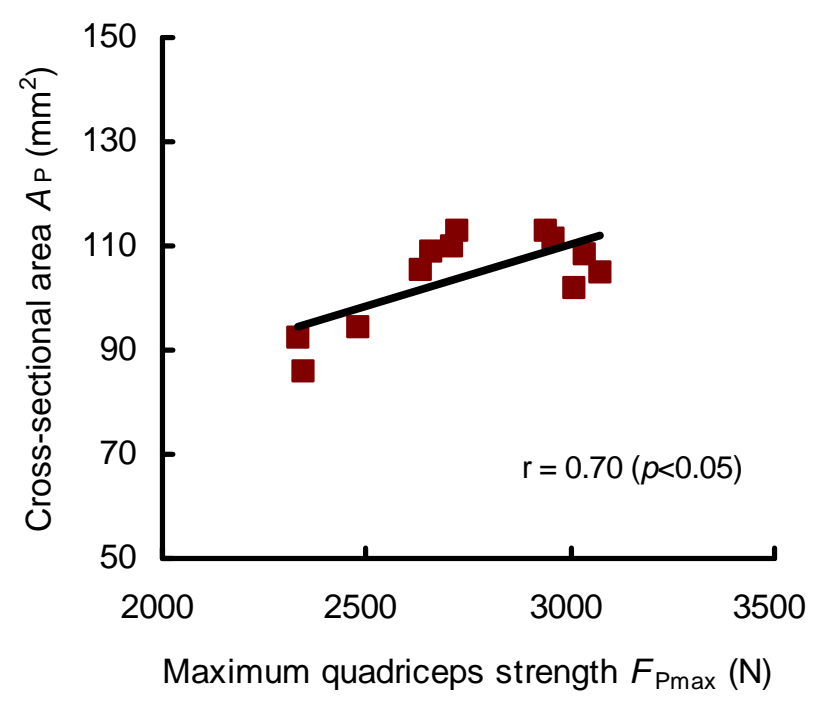

Fig. 6 Relationship between the patellar tendon cross-sectional area and the maximum quadriceps strength.

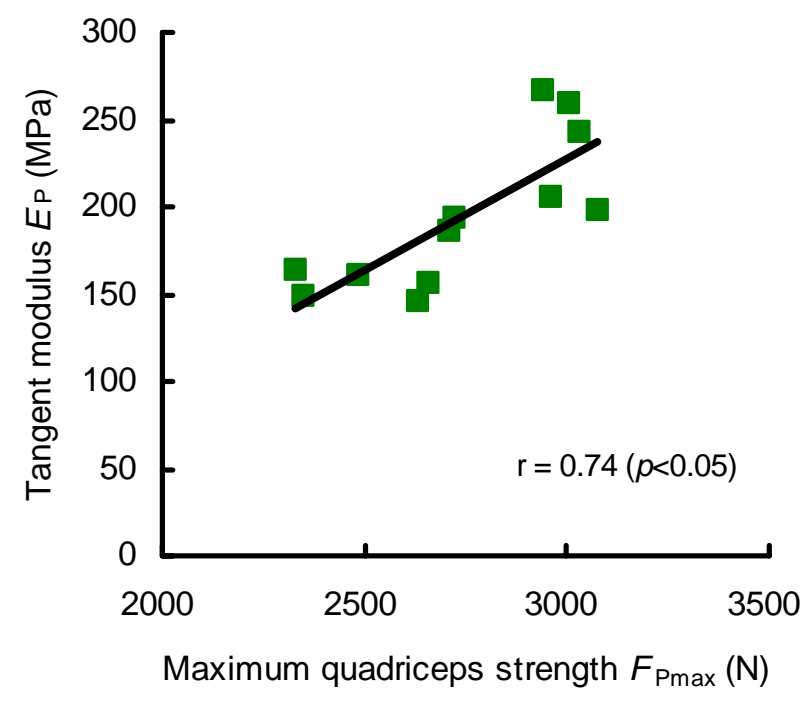

Fig. 7 Relationship between the patellar tendon tangent modulus and the maximum quadriceps strength.

\section{$3 \cdot 2$ 前十勒帯の力学的性質と大腿四頭筋の最大筋力の関係}

100Nを越える荷重を脛骨に繰り返しかけたときの荷重と移動量の典型的な関係を図 8 に示す. 数回の負荷と除 荷を繰り返すと図のように安定して計測できるようになった。10 回目に得られた結果において，荷重 100Nでの 移動量を求め, この值を脛骨の前方移動量 $D_{\mathrm{TA}}$ とした.

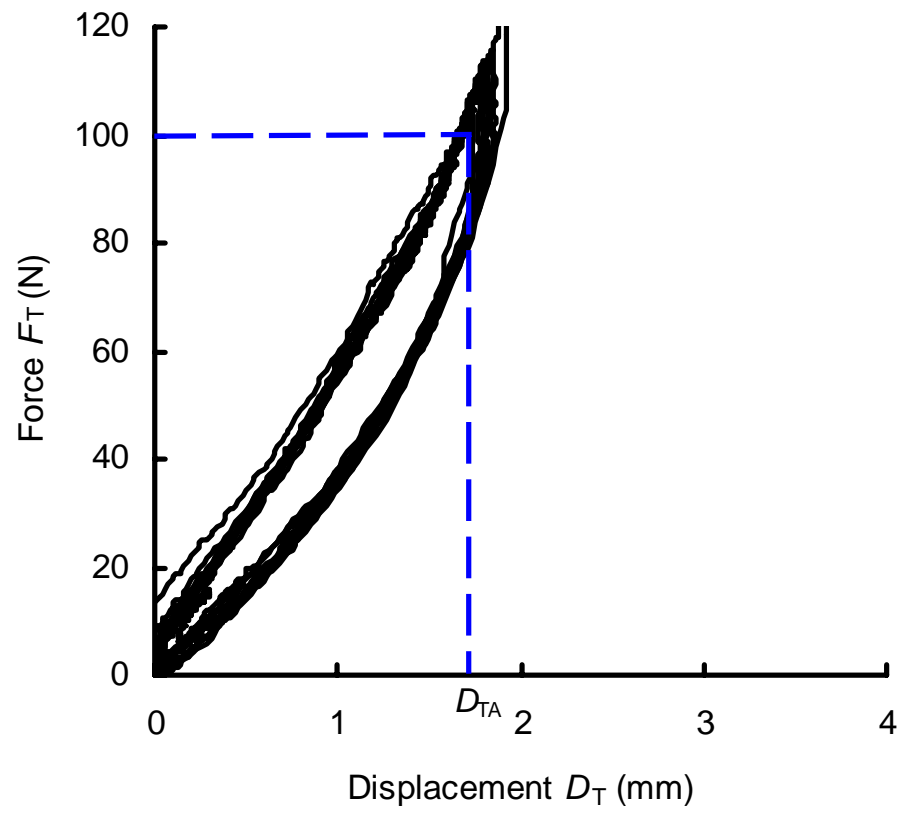

Fig. 8 Typical force-displacement curves during the anterior drawer of the tibia.

被験者 12 名における脛骨の前方移動量と大腿四頭筋の最大筋力の関係を図 9 に示寸. 前方移動量と最大筋力の 間に有意な相関関係は見られず，最大筋力が大きくなっても前方移動量は変わらなかった. 


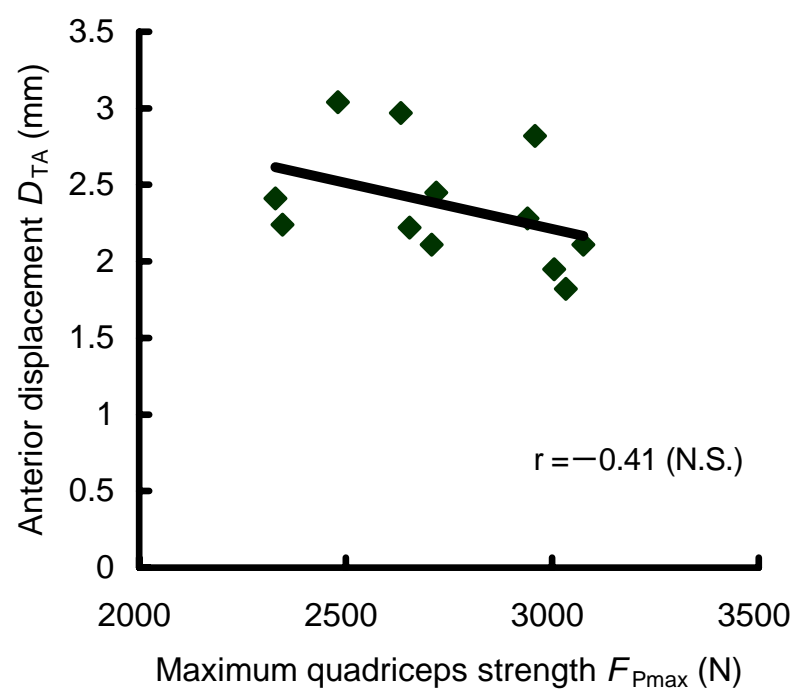

Fig. 9 Relationship between the anterior displacement of tibiae and the maximum quadriceps strength.

\section{4. 考察}

本実験では, 大腿四頭筋の最大筋力が大きな被験者では, 膝蓋腱の剛性, 断面積, 接線弾性係数が大きくなっ た. 筋力トレーニングなどの運動によって大腿四頭筋に生じる力が大きくなると大腿四頭筋の最大筋力が増大す ることは明らかである ${ }^{(12)(15)(16)(18)-(20)}$. このため, 大腿四頭筋の最大筋力が大きな被験者では, 日常的に大腿四頭筋 に大きな力が生じていることになる. 膝蓋腱は大腿四頭筋の力を脛骨に伝達する働きを担っているので, 大腿四 頭筋の最大筋力が大きな被験者では, 膝蓋腱に作用寸る負荷も大きくなる. この負荷増大に反応して, 膝蓋腱の 断面積と接線弾性係数が大きくなり, 腱全体の剛性が大きくなったと考えられる.

Kongsgaardら ${ }^{(15)}$ は, 被験者に対して膝伸展による筋力トレーニングを実施し, 膝蓋腱の力学的性質を本実験と 同様の方法で計測している．その結果，トレーニングの負荷が大きい膝では膝蓋腱の剛性が増大寸るが，負荷が 小さい膝では剛性は変化しなかったと報告している. 本実験においても，同様に大腿四頭筋の最大筋力が大きな 被験者では，膝蓋腱の岡性が大きくなっている．これらの結果から，膝蓋腱のリモデリングには，膝蓋腱に作用 する負荷の大きさが重要であることが示唆される．また，Kuboら ${ }^{(18)}$ は，被験者の一方の膝には等尺性収縮による 膝伸展のトレーニングを行い, 他方の膝では等張性収縮によるトレーニングを行い, 膝蓋腱の力学的性質の相違 について検討している，等尺性収縮のトレーニングでは膝蓋腱の剛性が有意に増大したが，等張性収縮では剛性 は変化しなかったと述べている，以上のことから, 膝蓋腱のリモデリングには, 膝蓋腱に作用する負荷の大きさ だけでなく, 様式も影響を及ぼすことが示唆される. 従来の研究では, これらの影響因子が十分にコントロール されずに実験が行われていたために，各々の研究で得られた結果に相違が生じていたと考えられる.

本実験では，脛骨の前方移動量と大腿四頭筋の最大筋力の間に有意な相関関係は見られなかったので，最大筋 力が大きな被験者でも前十字勒帯の剛性は変化しないことになる.一方, 膝蓋腱では剛性が大きくなっており, 両者で異なる結果が得られた。 この原因として以下の 2 つのこが考えられる. 膝蓋腱は大腿四頭筋と脛骨を連 結して筋力を脛骨に伝達する働きを担っているので，大腿四頭筋の筋力が膝蓋腱に直接作用する，一方，前十字 勒帯は大腿骨と脛骨を連結して脛骨に作用寸る筋力や外力に抗して膝を安定させる働きを担っているので，大腿 四頭筋の筋力が前十字勒帯に直接作用しているわけではない. このため, 前十字勒帯の剛性と大腿四頭筋の最大 筋力の関係に有意な相関が見られなかったと考えられる. また, 膝蓋腱に比べて前十字勒帯では力学的に適応す る能力が低いことが示唆される．膝蓋腱は線維芽細胞や血管が豊富な周囲組織に覆われており，リモデリングに は周囲組織からの線維芽細胞の進入や血流が関与していることが報告されている(23)-(25). 一方, 前十字勒帯は膝関 節内にあり, 周囲は関節液に接しているので, 膝蓋腱に比べてリモデリングに必要な線維芽細胞や血流を取り込 みにくいと考えられる. 
従来，リモデリングに関する研究は，実験動物を用いて行われてきた．イヌやブタなどをトレッドミル上で運 動させた後, 腱や勒帯を摘出し, 引張試験が行われている. 動物種や運動量などが各実験で異なっているので, 力学的性質にかなりのばらつきが見られるが，勒帯よりも腱において岡性が大きくなる傾向が見られた(1)(4)-(9).

前十字勒帯損傷によって起こる膝の不安定性を定量的に評価するために, 種々の測定器が開発されている(26)-(28). これらを用いて, 脛骨に前方荷重を作用させると, 健常膝に比べて前十字勒帯損傷膝では, 脛骨の前方移動量が 増大することが報告されている. Fleming ${ }^{(29)}$ らは, これらの研究結果についてまとめており, 測定器の種類や測定 者によりばらつきはあるが，健常膝においては，前方荷重 89〜100 Nで脛骨の前方移動量が 1.6〜 7.8 mmであった と報告している. 本実験で得られた前方荷重 100Nでの脛骨の前方移動量は 1.8〜 $3.0 \mathrm{~mm}$ とっており, 過去に報 告された前方移動量の範囲内であった.

Wooら ${ }^{(30)}$ は, ヒト死体膝を用いて, 脛骨の前後方引き出し試験を行なった後, 前十字勒帯の引張試験を行なっ ている．老年に比べて若年では，前十字勒帯の剛性が有意に大きくなったが，脛骨の前後方移動量は小さくなっ たものの，有意差は現れなかったと報告している．これは，作用させた前後方荷重が小さかったことや前十字勒 帯以外の周囲組織の影響に原因があると述べられている．また，ヒト死体膝を用いた生体外実験で，脛骨に前方 荷重を作用させたときに前十字勒帯に生じる張力が計測されているが，膝の拘束条件により得られた值に相違が 生じることが報告されている(31)(32). 以上のように, 前方引き出し試験から前十字勒帯の剛性を推定する際には, 種々の条件が計測結果に影響を及ぼすので, 注意が必要である. とくに, 本実験のような生体内実験では, 筋収 縮が実験結果に大きな影響を及ぼすので, 試験中は, 被験者には膝に力を入れないようにリラックスしてもらい, 筋収縮が起こらないように十分注意した。

\section{5. 結言}

本研究では, 12 名の被験者において, 膝蓋腱と前十字勒帯の力学的性質を評価し, 大腿四頭筋の最大筋力との 関係について検討した. 膝蓋腱の剛性, 断面積, 接線弾性係数は大腿四頭筋の最大筋力と有意な相関関係にあり, 最大筋力が大きいほど剛性, 断面積, 接線弾性係数は大きくなった. 一方, 脛骨の前方移動量と大腿四頭筋の最 大筋力の間に有意な相関関係は見られなかった．以上の結果から，大腿四頭筋の最大筋力が大きな被験者では， 膝蓋腱の剛性, 断面積, 接線弾性係数が大きくなるが, 前十字勒帯の岡性に変化は見られないことが明らかにな った.

\section{謝 辞}

本研究の一部は, 文部科学省社会連携研究推進事業（平成 19 年度〜平成 23 年度）により行った.

\section{文献}

(1) Cabaud, H.E., Chatty, A., Gildengorin, V., and Feltman, R.J., "Exercise Effects on the Strength of the Rat Anterior Cruciate Ligament”, The American Journal of Sports Medicine, Vol. 8 (1980), pp. 79-86.

(2) Hayashi, K., "Biomechanical Studies of the Remodeling of Knee Joint Tendons and Ligaments", Journal of Biomechanics, Vol. 29 (1996), pp. 707-716.

(3) Laros, G.S., Tipton, C.M., and Cooper, R.R., "Influence of Physical Activity on Ligament Insertions in the Knees of Dogs", The Journal of Bone and Joint Surgery, Vol. 53-A (1971), pp. 275-286.

(4) Viidik, A., "Elasticity and Tensile Strength of the Anterior Cruciate Ligament in Rabbits as Influenced by Training", Acta physiologica Scandinavica, Vol. 74 (1968), pp. 372-380.

(5) Wang, C.W., Weiss, J.A., Albright, J.P., Buckwalter, J.A., and Woo, S.L-Y., "The Effects of Long Term Exercise on the Structural and Mechanical Properties of the Canine Medial Collateral Ligament”, 1989 Biomechanics Symposium (1989), pp. 69-72, The American Society of Mechanical Engineers. 
(6) Woo, S.L-Y., Kuei, S.C., Gomez, M.A., Winters, J.M., Amiel, D., and Akeson W.H., "The Effect of Immobilization and Exercise on the Strength Characteristics of Bone-Medial Collateral Ligament-Bone Complex”, 1979 Biomechanics Symposium (1979), pp. 67-70, The American Society of Mechanical Engineers.

(7) Woo, S.L-Y., Ritter, M.A., Amiel, D., Sanders, T.M., Gomez, M.A., Kuei, S.C., Grafin S.R., and Akeson, W.H., “The Biomechanical and Biochemical Properties of Swine Tendons: Long Term Effects of Exercise on the Digital Extensors”, Connective Tissue Research, Vol. 7 (1980), pp. 177-183.

(8) Woo, S.L-Y., Gomez, M.A., Amiel, D., Ritter, M.A., Gelberman, R.H., and Akeson, W.H., "The Effects of Exercise on the Biomechanical and Biochemical Properties of Swine Digital Flexor Tendons”, Transactions of the ASME, Journal of Biomechanical Engineering, Vol. 103 (1981), pp. 51-56.

(9) Woo, S.L-Y., Gomez, M.A., Woo, Y.K., and Akeson, W.H., "Mechanical Properties of Tendons and Ligaments II: The Relationships of Immobilization and Exercise on Tissue Remodeling”, Biorheology, Vol. 19 (1982), pp. 397-408.

(10) Yamamoto, N., Hayashi, K., Hayashi, F., Yasuda, K., and Kaneda, K., “Biomechanical Studies of the Rabbit Patellar Tendon After Removal of Its One-Fourth or a Half”, Transactions of the ASME, Journal of Biomechanical Engineering, Vol. 121 (1999), pp. 323-329.

(11) Arampatzis, A., Karamanidis, K., and Albracht, K., “Adaptational Responses of the Human Achilles Tendon by Modulation of the Applied Cyclic Strain Magnitude”, The Journal of Experimental Biology, Vol. 15 (2007), pp. 2743-2753.

(12) Couppe, C., Kongsgaard, M., Aagaard, P., Hansen, P., Bojsen-Moller, J., Kjaer, M., and Magnusson, S.P., "Habitual Loading Results in Tendon Hypertrophy and Increased Stiffness of the Human Patellar Tendon”, Journal of Applied Physiology, Vol. 105 (2008), pp. 805-810.

(13) Hansen, P., Aagaard, P., Kjaer, M., Larsson, B., and Magnusson, S.P., “The Effect of Habitual Running on Human Achilles Tendon Load-Deformation Properties and Cross-Sectional Area”, Journal of Applied Physiology, Vol. 95 (2003), pp. 2375-2380.

(14) Kongsgaard, M., Aagaard, P., Kjaer, M., and Magnusson, S.P., "Structural Achilles Tendon Properties in Athletes Subjected to Different Exercise Modes and in Achilles Tendon Rupture Patients”, Journal of Applied Physiology, Vol. 99 (2005), pp. 1965-1971.

(15) Kongsgaard, M., Reitelseder, S., Pedersen, T.G., Holm, L., Aagaard, P., Kjaer, M., and Magnusson, S.P., "Region Specific Patellar Tendon Hypertrophy in Humans Following Resistance Training”, Acta physiologica, Vol. 191 (2007), pp. 111-121.

(16) Kubo, K., Yata, H., Kanehisa, H., and Fukunaga, T., "Effects of Isometric Squat Training on the Tendon Stiffness and Jump Performance”, European Journal of Applied Physiology, Vol. 96 (2006), pp. 305-314.

(17) Kubo, K., Morimoto, M., Komuro, T., Yata, H., Tsunoda, N., Kanehisa, H., and Fukunaga, T., "Effects of Plyometric and Weight Training on Muscle-Tendon Complex and Jump Performance”, Medicine and Science in Sports and Exercise, Vol. 39 (2007), pp. 1801-1810.

(18) Kubo, K., Ikebukuro, T., Yaeshima, K., Yata, H., Tsunoda, N., and Kanehisa, H., "Effects of Static and Dynamic Training on the Stiffness and Blood Volume of Tendon In Vivo”, Journal of Applied Physiology, Vol. 106 (2009), pp. 412-417.

(19) Reeves, N.D., Maganaris, C.N., and Narici, M.V., "Effect of Strength Training on Human Patella Tendon Mechanical Properties of Older Individuals”, The Journal of Physiology, Vol. 548 (2003), pp. 971-981.

(20) Reeves, N.D., Narici, M.V., and Maganaris, C.N., "Strength Training Alters the Viscoelastic Properties of Tendons in Elderly Humans”, Muscle \& Nerve, Vol. 28 (2003), pp. 74-81.

(21) Yamamoto, N. and Ota, T., "Relationships between the Mechanical Properties of Patellar Tendons and Quadriceps Strength in Humans”, Journal of Biomechanical Science and Engineering, Vol. 4 (2009), pp. 530-538.

(22) Butler, D.L., Noyes, F.R., and Grood, E.S., “Ligamentous Restraints to Anterior-Posterior Drawer in the Human Knee”, The Journal of Bone and Joint Surgery, Vol. 62-A (1980), pp. 259-270.

(23) 山本憲隆, 林紘三郎, “家兔膝蓋腱の力学的性質に及ぼす Stress shielding の影響一線維芽細胞の侵入抑制の効果に ついてー”, 日本臨床バイオメカニクス学会誌, Vol. 16 (1995), pp. 119-122.

(24) Tohyama, H. and Yasuda, K., "The Effects of Stress Enhancement on the Extracellular Matrix and Fibroblasts in the Patellar Tendon”, Journal of Biomechanics, Vol. 33 (2000), pp. 559-565. 
（25）遠山晴一, 安田和則, “内在性線維芽細胞および外来性浸潤細胞の存在が過負荷膝蓋腱の力学的性質に及ぼす影響”, 日本臨床バイオメカニクス学会誌，Vol. 21 (2000), pp. 127-132.

(26) Markolf. K., Kochan, A., and Amstutz, H., "Measurement of Knee Stiffness and Laxity in Patients with Documented Absence of the Anterior Cruciate Ligament”, The Journal of Bone and Joint Surgery, Vol. 66-A (1984), pp. 242-253.

(27) Daniel, D., Malcom, L., Losse, G., Stone, M., Sachs, R., and Burks, R., "Instrumented Measurement of Anterior Laxity of the Knee”, The Journal of Bone and Joint Surgery, Vol. 67-A (1985), pp. 720-726.

(28) Boniface, R., Fu, F., and Ilkhanipour, K., “Objective Anterior Cruciate Ligament Testing”, Orthopedics, Vol. 9 (1986), pp. 391-393.

(29) Fleming, B.C., Beynnon, B.D., and Johnson, R.J., “The Use of Knee Laxity Testers for the Determination of Anterior-Posterior Stability of the Knee”, The Anterior Cruciate Ligament: Current and Future Concepts (1993), pp. 239-250, Raven Press.

(30) Woo, S.L-Y., Hollis, J.M., Adams, D.J., Lyon, R.M., and Takai, S., “Tensile Properties of the Human Femur-Anterior Cruciate Ligament-Tibia Complex: The Effects of Specimen Age and Orientation”, The American Journal of Sports Medicine, Vol. 19 (1991), pp. 217-224.

（31）藤江裕道，馬㴊清資，渡辺尚，北爪伸仁，塚本行男，村石明彦，笹田直，“前十字勒帯および後十字勒帯に生じる 張力とその分布”，日本臨床バイオメカニクス学会誌，Vol. 16 (1995), pp. 147-151.

(32) Takai, S., Woo, S.L-Y., Livesay, G.A., Adams, D.J., and Fu, F.H., "Determination of the In-Situ Loads on the Human Anterior Cruciate Ligament”, Journal of Orthopaedic Research, Vol. 11 (1993), pp. 686-695. 